\title{
John Virgo and the Best Undergraduate Paper Competition
}

\author{
Gary E. Clayton
}

Published online: 31 July 2013

(C) International Atlantic Economic Society 2013

In the aftermath of Dr. John Virgo's unfortunate and untimely death, many of us who knew him have paused to reflect on the many contributions he has made to economics. Most people probably know of his work founding the International Atlantic Economic Society, the first and most significant organization to bring economists together from both sides of the Atlantic Ocean. In so doing, he was hugely successful, as the society has had significant participation every year since its founding in 1973 . With two annual conferences, one on each side of the Atlantic, and with two refereed publications, he more than accomplished his goal of "increasing global communication among economists across continents." What most people don't know, however, is the impact that John had on a generation of much younger and, we hope, future economists.

It all started in an IAES executive committee meeting during the fall of 2004 when we were discussing things we could do to make the economics profession attractive to undergraduate students. After some debate, there was agreement that a competition featuring undergraduate authored papers would be possible, but there were several major obstacles that had to be overcome. First, the competition had to feature a decent cash reward to make it attractive to students. So, it was decided that an annual $\$ 500$ award, along with commemorative plaques to the winner and the runners-up, would be sufficient. While seemingly the most difficult problem, it was also the easiest to solve, as the owner of the www.EconSources.com website offered a modest endowment to the Society to cover the expenses for a period of approximately ten years. ${ }^{1}$ It was also decided that the competition would feature a presentation of the very best papers to a panel of judges who would make the overall best undergraduate paper selection. When we talked about the problem of what to do with the winning paper, John Virgo graciously offered to publish it in the Atlantic Economic Journal at no

\footnotetext{
${ }^{1}$ Disclosure is called for here as EconSources.com, a non-commercial site that has no ads and generates no revenue, is my personal website. It is simply maintained as a tool for students and members of the general public who may be interested in economics.
}

G. E. Clayton $(\bowtie)$

Northern Kentucky University, Highland Heights, KY, USA

e-mail: clayton@nku.edu 
charge to the student. This increased the value of the competition to the winner, and it ensured a degree of transparency so that others could compare their work to one selected by the judges.

Another problem was how to make sure that the students showed up at the conference if their papers were selected. The solution came when one of the executive committee members suggested that we ask the student's university to sponsor their student's lodging and air fare to the conference. We had some concern that a requirement like this as a condition for entering the competition might be too stringent, but it turned out to be the best way to deal with a potentially difficult issue. As it was, we've had perfect attendance in each of our eight years.

There were a lot of decisions made in that executive committee meeting of 2004, but there was general agreement that we had a reasonable framework, and all we had to do next was implement it. Everyone on the executive committee had a hand in shaping the competition, and John Virgo was ever present with his timely advice and encouragement. In fact, the competition would not have been possible without him.

Fliers announcing the first competition went out shortly after that, and we hoped that the competition would mirror the Society's objectives of attracting an international audience. As it was, we had little to worry about as approximately 50 papers came in from six different countries. ${ }^{2}$ There were twice as many papers in the second year, and it resulted in our use of a two-tiered judging system that is still in place today.

The process works like this: First, announcements go out to everyone on the extensive IAES mailing list, and the competition is also promoted at each of the annual IAES conferences. Then, in May, another mailing is made inviting people to serve as judges. Respondents who want to participate as judges are then divided into two categories. The first round judges are those who are willing to select their favorite four or five papers from a batch of about 40 to $50 .{ }^{3}$ The second round judges are those who can attend the conference and observe the presentations of the four finalists. The number of judges varies every year, but 10-15 are involved in the first round while four are needed to attend the conference. It's also important to note that all information identifying the student and the student's institution are removed before the judges see any of the papers. Occasionally the issue studied is country or location specific, but other than that, the authors of the papers are completely anonymous.

Participation by the judges has been a pleasant surprise. During the eight years of competition, we've had 82 different judges from 75 different institutions. Even more surprising, the judges have come from 22 different countries, something which helps to ensure the international flavor of the competition (see Table 1). ${ }^{4}$ In the 2012 year alone, first round judges were from P.R. China, India, Italy, Poland, South Korea, and

\footnotetext{
${ }^{2}$ While I remember the first year clearly, I have come to regret the fact that I did not keep detailed records for each of the eight competitions held so far. However, some summary statistics can be derived for the list of finalists and winners in Table 2.

${ }^{3}$ We normally receive more than 50 papers, so the weaker ones are set aside so as to not unnecessarily burden the first round judges. Making hard copies of 80-100 papers to mail to each of the judges would hardly be feasible.

${ }^{4}$ Most of the judges who participated in the first round of judging received hard copies of the papers in the mail; a few requested PDF versions.
} 
Table 1 Distribution of judges by country, 2005-12 best undergraduate paper competition

\begin{tabular}{lll}
\hline Australia & India & Portugal \\
Brazil & Italy & Romania \\
Canada & Japan & South Africa \\
P.R. China & South Korea & Spain \\
Czech Republic & Malaysia & Sweden \\
Germany & The Netherlands & Turkey \\
Greece & Poland & United Arab Emirates \\
& & United States \\
\hline
\end{tabular}

the United States - while the four finalist papers they selected were from Denmark, the United Kingdom, and the United States.

Finally, the day of the conference arrives and John Virgo has gone out of his way to make everyone as welcome as possible. The students have been told that they could bring their parents, significant others, or companions to the competition as guests of the IAES. John also had the IAES staff prepare name tags and program brochures for each of the students, and plaques with the students' names and paper titles are on display in the conference lobby. ${ }^{5}$ The only thing left to do is to have the presentation session so that the judges can choose the winner.

The presentations in the student session are almost always outstanding. John told me on several occasions that the student sessions were one of his favorites and he was able to attend most of them. Maybe it was because of the youthful optimism the students had, or maybe it was because of the exceptional preparation and detailed analysis they demonstrated. Maybe it was even because we had succeeded in our original goal of bringing top economic students together from all over the world, many of whom we expected to go on to graduate programs or other significant careers in economics. Table 2 shows a list of all of the winners and finalists since 2005. The international flavor of the competition is evidenced by the fact that 14 of the 33 students were from universities in nine different countries. As for their topics, the variety of undertakings defies classification.

As for the students in the competition, we know that at least nine of those listed in Table 2 have gone on to graduate programs (including Cambridge, the University of Cassino, Harvard, the London School of Economics, M.I.T., Michigan, and Oxford). This is hardly a comprehensive list however, because we never sought to track the careers of our students. Like most in the teaching profession, we really never know who we have influenced or who will be the most successful, so all we can do is make a good effort when they are in our sphere of influence and hope that we have helped them along the way.

While we can certainly call the Best Undergraduate Paper Competition a success by now, this report comes with a note of sadness. John Virgo and I often talked about doing something like a ten-year summary because, well, I suppose, because ten is a

\footnotetext{
5 The winning student will have his or her plaque changed from "finalist" to "winner," as the final outcome will not be known until after the presentations are made and the judges cast their votes.
} 
Table 2 Best undergraduate paper finalists and winners, 2005-2012

\begin{tabular}{|c|c|c|c|c|}
\hline Year & Student & Paper & University & Country \\
\hline 2012 & Colin Gray & $\begin{array}{l}\text { Responding to a Monetary } \\
\text { Superpower: Investigating the } \\
\text { Behavioral Spillovers of U.S. } \\
\text { Monetary Policy }\end{array}$ & $\begin{array}{l}\text { Stanford } \\
\text { University }\end{array}$ & U.S.A. \\
\hline 2012 & Boris Georgiev & $\begin{array}{l}\text { Implications of Public Debt on Economic } \\
\text { Growth and Development }\end{array}$ & $\begin{array}{l}\text { Aarhus } \\
\text { University }\end{array}$ & Denmark \\
\hline 2012 & Dana Simonson & $\begin{array}{l}\text { Has the Switch from Food Stamps to the } \\
\text { EBT Card Affected an Individual's } \\
\text { Decision to Participate in the Food } \\
\text { Stamp Program? }\end{array}$ & $\begin{array}{l}\text { Minnesota State } \\
\text { University }\end{array}$ & U.S.A. \\
\hline 2012 & Jia Yi Leong & $\begin{array}{l}\text { Price Dispersion in Online Grocery } \\
\text { Stores: An Analysis of the UK Market }\end{array}$ & $\begin{array}{l}\text { University of } \\
\text { Warwick }\end{array}$ & $\begin{array}{l}\text { United } \\
\text { Kingdom }\end{array}$ \\
\hline 2011 & $\begin{array}{l}\text { Giacomo Saibene } \\
\text { \& Silvia Sicouri }\end{array}$ & $\begin{array}{l}\text { The Effects of Currency Devaluations } \\
\text { on the Economic Growth in } \\
\text { Developing Countries }\end{array}$ & $\begin{array}{l}\text { Politecnico di } \\
\text { Milano }\end{array}$ & Italy \\
\hline 2011 & Matthew Cook & $\begin{array}{l}\text { Voting with Bidirectional Elimination } \\
\text { Effects }\end{array}$ & $\begin{array}{l}\text { Stanford } \\
\text { University }\end{array}$ & U.S.A. \\
\hline 2011 & $\begin{array}{l}\text { Gregory } \\
\text { Hirshman }\end{array}$ & $\begin{array}{l}\text { Raising Taxes to Balance the Budget: } \\
\text { How Effects on Output and Labor } \\
\text { Supply Complicate the Issue }\end{array}$ & $\begin{array}{l}\text { Stanford } \\
\text { University }\end{array}$ & U.S.A. \\
\hline 2011 & Brad Stanger & The Subprime Myth & $\begin{array}{l}\text { Princeton } \\
\text { University }\end{array}$ & U.S.A. \\
\hline 2010 & $\begin{array}{l}\text { Anders Ditlev } \\
\text { Jensen }\end{array}$ & $\begin{array}{l}\text { State-Building in Resource-Rich } \\
\text { Economies: How Mother Nature } \\
\text { Impedes Fiscal Capacity }\end{array}$ & $\begin{array}{r}\text { London School } \\
\text { of Economics }\end{array}$ & $\begin{array}{l}\text { United } \\
\text { Kingdom }\end{array}$ \\
\hline 2010 & Alicia M. Frank & $\begin{array}{l}\text { The Effect of Tree Cover on Home } \\
\text { Sale Price }\end{array}$ & Davidson College & USA \\
\hline 2010 & Yoon Won Song & $\begin{array}{l}\text { The Effects of Renewable Energy } \\
\text { Policies on the Contribution of } \\
\text { Renewable Energy Sources in Total } \\
\text { Energy Production }\end{array}$ & $\begin{array}{l}\text { Princeton } \\
\text { University }\end{array}$ & U.S.A. \\
\hline 2010 & Gabriel Tourek & $\begin{array}{l}\text { Assessing "Wisconsin Works": An } \\
\text { Evaluation of the Impact of State } \\
\text { Responses to Welfare Reform on } \\
\text { the Earnings and Employment of } \\
\text { Single Mothers, 1990-2000 }\end{array}$ & $\begin{array}{l}\text { University of } \\
\text { Michigan }\end{array}$ & U.S.A. \\
\hline 2009 & $\begin{array}{r}\text { Markus Gstoettner } \\
\text { \& Anders Jensen }\end{array}$ & $\begin{array}{l}\text { Aid and Public Finance: A Missing } \\
\text { Link }\end{array}$ & $\begin{array}{r}\text { London School } \\
\text { of Economics }\end{array}$ & $\begin{array}{l}\text { United } \\
\text { Kingdom }\end{array}$ \\
\hline 2009 & Katarzyna Janczura & $\begin{array}{l}\text { Price Volatility and the Efficient Energy } \\
\text { Profile for the United States }\end{array}$ & $\begin{array}{l}\text { New York } \\
\text { University }\end{array}$ & U.S.A. \\
\hline 2009 & Arun Advani & $\begin{array}{l}\text { How Do House Price Booms Affect } \\
\text { Consumption? Recent Evidence in } \\
\text { the U.K. }\end{array}$ & $\begin{array}{l}\text { King's College- } \\
\text { Cambridge }\end{array}$ & $\begin{array}{l}\text { United } \\
\text { Kingdom }\end{array}$ \\
\hline 2009 & Petra Vujakovic & $\begin{array}{l}\text { How to Measure Globalization? A New } \\
\text { Globalization Index (NGI) }\end{array}$ & $\begin{array}{l}\text { Vienna University } \\
\text { of Economics \& } \\
\text { Business }\end{array}$ & Austria \\
\hline 2008 & Maxim Pinkovskiy & $\begin{array}{l}\text { Rational Inattention and Choice } \\
\text { Under Risk: Explaining Violations } \\
\text { of Expected Utility }\end{array}$ & $\begin{array}{l}\text { Columbia } \\
\text { University }\end{array}$ & U.S.A. \\
\hline
\end{tabular}


Table 2 (continued)

\begin{tabular}{|c|c|c|c|c|}
\hline Year & Student & Paper & University & Country \\
\hline & & $\begin{array}{l}\text { Through a Shannon Entropy } \\
\text { Formulation of the Costs of } \\
\text { Rationality }\end{array}$ & & \\
\hline 2008 & Christoph Lakner & $\begin{array}{l}\text { Why Does Microfinance Not Reach } \\
\text { the Poorest? }\end{array}$ & $\begin{array}{l}\text { Oxford } \\
\text { University }\end{array}$ & $\begin{array}{l}\text { United } \\
\text { Kingdom }\end{array}$ \\
\hline 2008 & Maurizio Montone & $\begin{array}{l}\text { The Phenomenon of Arbitrages in the } \\
\text { Global Betting Market: Theoretical } \\
\text { Framework and Empirical Analysis }\end{array}$ & $\begin{array}{l}\text { University of } \\
\text { Naples } \\
\text { Federico II }\end{array}$ & Italy \\
\hline 2008 & $\begin{array}{l}\text { Sheila } \\
\text { Ramachandra }\end{array}$ & $\begin{array}{l}\text { Higher Education and Non-Profit } \\
\text { Governance: The Role of Endowments }\end{array}$ & $\begin{array}{l}\text { Rutgers } \\
\text { University }\end{array}$ & U.S.A. \\
\hline 2007 & $\begin{array}{l}\text { Zach Devlin-Foltz } \\
\text { \& Katherine Lim }\end{array}$ & $\begin{array}{l}\text { Motivations for "Non-Rational" } \\
\text { Punishment in Public Goods } \\
\text { Settings: An Experimental Analysis }\end{array}$ & $\begin{array}{l}\text { Macalester } \\
\text { College }\end{array}$ & U.S.A. \\
\hline 2007 & Kathryn Clark & $\begin{array}{l}\text { Recasting the DICE: Endogenous } \\
\text { Time Preference and Greenhouse } \\
\text { Gas Abatement Decisions }\end{array}$ & $\begin{array}{l}\text { Dartmouth } \\
\text { College }\end{array}$ & U.S.A. \\
\hline 2007 & Steven Englehardt & $\begin{array}{l}\text { Wage Inequality in the United States } \\
\text { During the 1990s: Have the Effects } \\
\text { of Outsourcing and Computers on } \\
\text { the Skills Premium Changed? }\end{array}$ & Boston College & U.S.A. \\
\hline 2007 & $\begin{array}{l}\text { Hande Eredinc \& } \\
\text { Jonyada Milla }\end{array}$ & $\begin{array}{l}\text { Analysis of Cointegration in Capital } \\
\text { Markets of France, Germany, and } \\
\text { the United Kingdom }\end{array}$ & $\begin{array}{l}\text { Marmara } \\
\text { University }\end{array}$ & Turkey \\
\hline 2006 & Jeffrey Wilson & $\begin{array}{l}\text { Peer Effects and Cigarette Use } \\
\text { among College Students }\end{array}$ & $\begin{array}{l}\text { University of } \\
\text { Akron }\end{array}$ & U.S.A. \\
\hline 2006 & Saleem Bahaj & $\begin{array}{l}\text { The Low Cost Phenomenon: An } \\
\text { Analysis of China's Deflationary } \\
\text { Impact on the U.S. Economy }\end{array}$ & $\begin{array}{l}\text { London School } \\
\text { of Economics }\end{array}$ & $\begin{array}{l}\text { United } \\
\text { Kingdom }\end{array}$ \\
\hline 2006 & Tatyana Deryugina & $\begin{array}{l}\text { Technology Adoption under Stochastic } \\
\text { Conditions: Drought Tolerant Crops } \\
\text { and Rainfall }\end{array}$ & $\begin{array}{l}\text { University of } \\
\text { California, } \\
\text { Berkley }\end{array}$ & U.S.A. \\
\hline 2006 & Ronald Turner & $\begin{array}{l}\text { The Impact of Inflation Targeting: } \\
\text { Lessons from Targeting Countries }\end{array}$ & $\begin{array}{l}\text { Villanova } \\
\text { University }\end{array}$ & U.S.A. \\
\hline 2005 & Matthew Lilling & $\begin{array}{l}\text { The Link Between CEO Compensation } \\
\text { and Firm Performance: Does } \\
\text { Simultaneity Matter? }\end{array}$ & $\begin{array}{l}\text { Emory } \\
\text { University }\end{array}$ & U.S.A. \\
\hline 2005 & Virginie Baudouhat & $\begin{array}{l}\text { Nordic Financial Market Integration: An } \\
\text { Analysis with GARCH Modeling }\end{array}$ & $\begin{array}{l}\text { Goteborg } \\
\text { University }\end{array}$ & Sweden \\
\hline 2005 & Rebecca Finan & $\begin{array}{l}\text { Gender Differentials in Earnings Among } \\
\text { Artists and Photographers in the United } \\
\text { States }\end{array}$ & $\begin{array}{c}\text { Northeastern } \\
\text { University }\end{array}$ & U.S.A. \\
\hline 2005 & Joelle Grospelier & $\begin{array}{l}\text { What Could Have Prompted Keynes to } \\
\text { Call Montesquieu "The Real } \\
\text { Equivalent of Adam Smith, The } \\
\text { Greatest of French Economists"? }\end{array}$ & Trinity College & Ireland \\
\hline 2005 & Yang Zhao & $\begin{array}{l}\text { A Welfare Analysis of Liberalization } \\
\text { in the Dutch Postal Market }\end{array}$ & $\begin{array}{l}\text { Tilburg } \\
\text { University }\end{array}$ & $\begin{array}{l}\text { The } \\
\text { Netherlands }\end{array}$ \\
\hline
\end{tabular}

Winners in bold; finalists otherwise 
nice round number. Unfortunately, John's untimely death has shortened the report by two years and he will not be around to read it. Even so, he supported the competition at every turn, and he was able to meet all of the fine students in the competition as well as their parents and significant others that attended as guests of the IAES. None of this would have been possible without his support, and hopefully this brief summary will help others understand the impact that John Virgo had on a generation of much younger and, we hope, future economists. 